\title{
Tooth in Intracranial Compartment after Traumatic Brain Injury
}

\section{Traumatismo cranioencefálico com perfuração intracraniana por dente}

\author{
Benedito J. A. Pereira ${ }^{1,2}$ Radmila Agra Cariry Targino de Holanda ${ }^{2}$ José Targino Neto ${ }^{2}$ \\ Luciano Ferreira de Holanda 2,3 \\ ${ }^{1}$ Department of Neurosurgery, Centro Especializado em Neurologia e \\ Neurocirurgia Associados (CENNA), Hospital Beneficência \\ Portuguesa de São Paulo, São Paulo, SP, Brazil \\ ${ }^{2}$ Department of Neurosurgery, Hospital Antônio Targino, Campina \\ Grande, PB, Brazil \\ ${ }^{3}$ Department of Medical Sciences, Faculdade de Medicina, \\ Universidade Federal de Campina Grande (UFCG), Campina Grande, \\ PB, Brazil \\ Arq Bras Neurocir 2017;36:26-28 \\ Address for correspondence Benedito Jamilson Araújo Pereira, MD, \\ Rua Martiniano de Carvalho, 669, Edifício Paulista Paradise Life, Apto \\ 1105, São Paulo, SP, Brazil (e-mail: benedito.jamilson@hotmail.com).
}

\begin{abstract}
Keywords

- traumatic brain injury

- tooth

- surgery

Resumo

Palavras-chave

- traumatismo cranioencefálico

- dente

- cirurgia

A 25-year-old patient was admitted to the emergency room presenting headaches after a traumatic brain injury (TBI) 30 days before, when he collided frontally with another driver. After a skull radiography, the presence of a foreign body was observed in the frontal sinus. A cranial computed tomography (CT) scan found that it was a tooth. The patient underwent surgical treatment for the removal of the tooth. Traumatic brain injury caused by non-missile penetrating objects is unusual, and has been described in case reports in the literature. To the best of our knowledge, no similar reports can be found in the literature.

Paciente com 25 anos de idade trazido à sala de emergência com quadro de cefaleia frontal , que não melhorava com uso de analgésicos. Apresentava história prévia de trauma de crânio (TCE) 30 dias antes, quando ele colidiu frontalmente com outro motorista. Após radiografia crânio, a presença de um corpo estranho foi observada no seio frontal. A tomografia computadorizada de crânio evidenciou a presença de um dente. $\mathrm{O}$ paciente foi submetido a tratamento cirúrgico para a remoção do dente. A evolução foi satisfatória, o paciente apresentava-se assintomática na alta hospitalar. TCE penetrantes são incomuns e são descritos na literatura na maioria das vezes como relatos de casos. Para o nosso conhecimento, não há relatos semelhantes em outras séries sobre o assunto.
\end{abstract}

\section{Case Report}

A 25 -year-old patient was admitted to the emergency room presenting frontal headaches, without improve- ment, despite the use of pain killers. The patient had suffered a traumatic brain injury (TBI) 30 days before, when he collided frontally with another driver. After a skull radiography, the presence of a foreign body was
Recebido

October 10, 2016

Aprovado

November 24, 2016
DOI http://dx.doi.org/

10.1055/s-0036-1597773. ISSN 0103-5355.
Copyright $\odot 2017$ by Thieme Revinter Publicações Ltda, Rio de Janeiro, Brazil
License terms

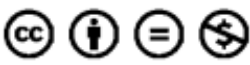




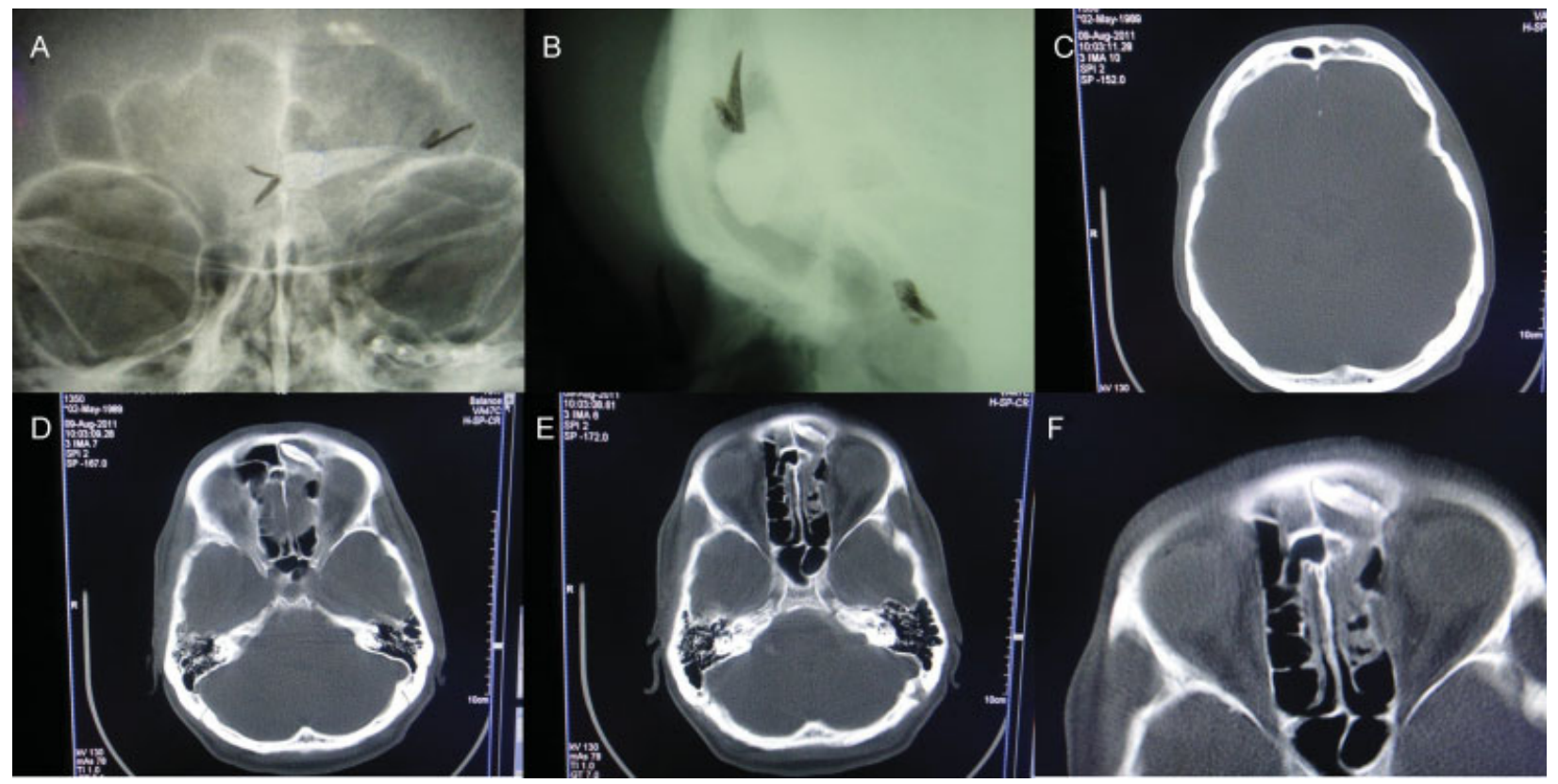

Fig. 1 Pre-operative images. (A, B): radiograph (AP and lateral view respectively) showing the presence of the tooth in the frontal sinus; (C): sinking present in the left frontal sinus; (D-F): axial CT scans (bone window) showing the presence of the tooth within the left frontal sinus.

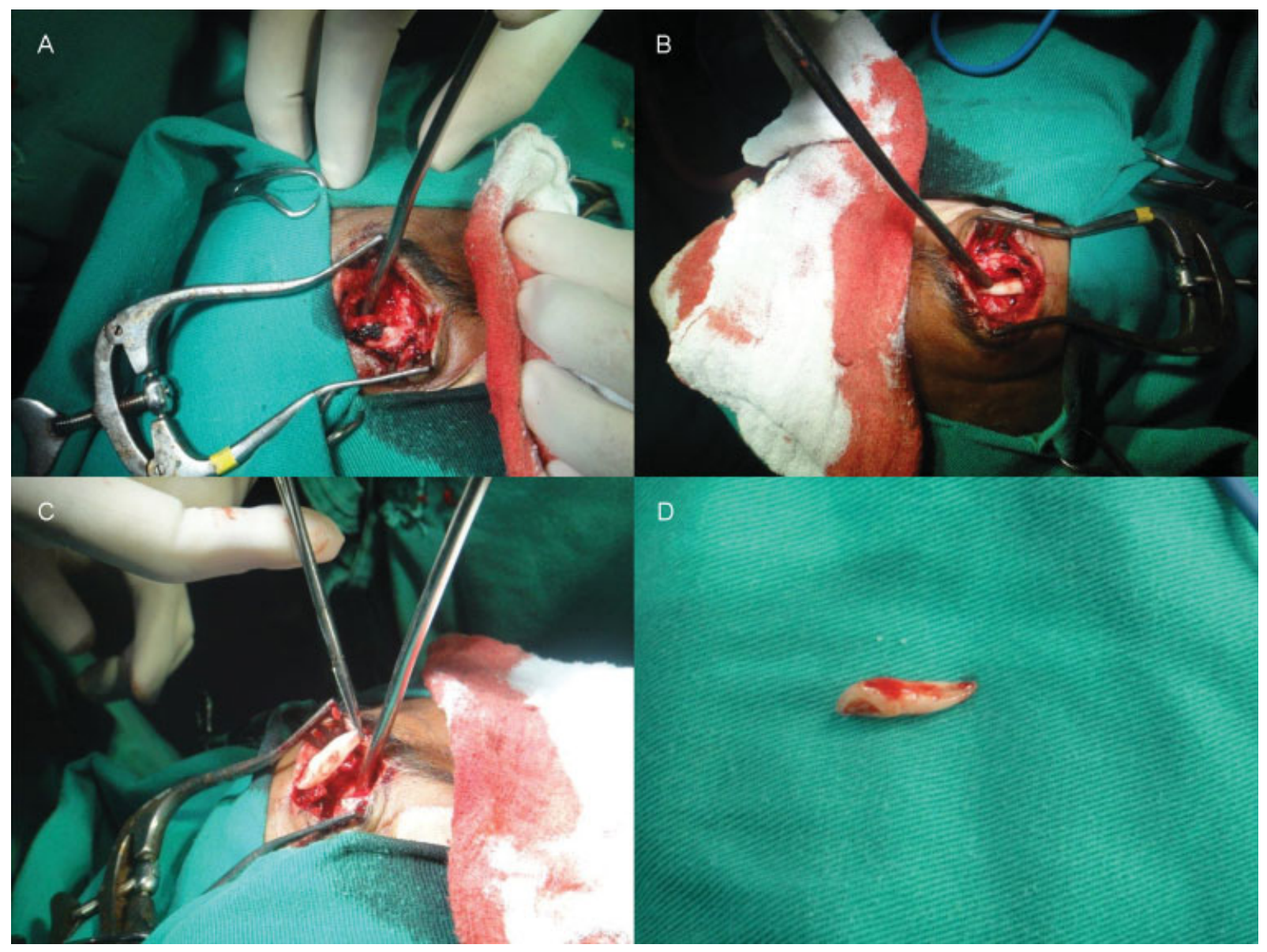

Fig. 2 Operative findings. (A-C): approach by eyebrow (step by step) to remove the tooth; (D): tooth after withdrawal. 
28 Tooth in Intracranial Compartment after TBI Pereira et al.

observed in the frontal sinus. A cranial computed tomography (CT) scan found that it was a tooth (-Fig. 1). The patient underwent surgical treatment (-Fig. 2) for the removal of the tooth. His evolution was satisfactory, and the patient was asymptomatic upon discharge.

Traumatic brain injury caused by non-missile penetrating objects is unusual, and has been described in case reports in the literature, ${ }^{1}$ and in some literature reviews that corroborate our management. ${ }^{2}$ The most likely justification for this trauma would be the fact that the patient was not wearing a helmet during the frontal collision, and unfortunately the other driver's tooth pierced his frontal sinus. To the best of our knowledge, no similar reports can be found in the literature.

\section{References}

1 Alafaci C, Caruso G, Caffo M, et al. Penetrating head injury by a stone: case report and review of the literature. Clin Neurol Neurosurg 2010;112(9):813-816

2 de Holanda LF, Pereira BJ, Holanda RR, et al. Neurosurgical Management of Nonmissile Penetrating Cranial Lesions. World Neurosurg 2016;90:420-429 